\title{
MILITARY TRAINING IN THE PUBLIC SCHOOLS
}

By Ping Ling

In these times of unparalleled storm and stress when all the national resources are being mobilized and all the public institutions are either requisitioned by the government or are themselves changing and reshaping their policies for the prosecution of the war, the educators in this country are constantly facing the problem: What can the public schools do in aiding the nation in this gigantic struggle? "We must win the war" is the sentence that springs to every lip and quickens the beats of every heart. But what can the schools contribute toward winning this war is the question which is pressing for answer.

Of all the war measures in which the schools can possibly take part, military training for the youth before he reaches his military age is a very important one. It is one which involves a great diversity of opinion among those who have been giving serious thought to the problem. The term military training is very elastic in its meaning and can be conceived by different people to mean different things. It is used alike by those who would like to turn the public schools into actual military camps and by those who would advocate the policy of giving the boys a broad physical education so as to enable them to become efficient soldiers later on when such general training is supplemented by technical military drill. Most of the pros and cons on this important problem are due to the different conceptions of the term rather than the uncompromising attitudes of those who discuss the two sides of the issue. The difference of opinion centers on the means and methods by which military training should be provided rather than its aim-which is to prepare the youth for efficient citizenship in peace or in war.

In collecting data on this important subject the writer has included in the questionnaire referred to in the other chapter the following question:

Have you military training in the high school, and if so, what, and how much time is given?

In addition to this questionnaire the writer has also endeavored to collect all the laws enacted or any bills being considered by the different state legislatures on this problem. 
At the time of this writing very few states in this country have had any law concerning military training in the public schools, and only one state has made such training compulsory for all able-bodied boys of certain age who are now receiving free public instruction. But from the returns of my questionnaire we find that in practically every state of the Union there are at least some cities which provide an elective course of military instruction for a sufficient number of students who wish to take it. The kind of instruction offered and the amount of time devoted to it are of such diverse nature that it would be impossible to present them in full without greatly lengthening this chapter. For this reason I choose to present here only the salient features of the laws and practices which we find elsewhere in this country.

\section{Laws and Practices of Military Training in Dif- FERENT School Systems}

Roughly speaking, the laws and practices of military training in different school systems can be classified according to the narrow and broad interpretations of the term military training. When it is taken in its narrow sense, it means that kind of training which consists of a few drills in each school week in the manual of arms and close-order formation. The kind of military training which we find in the public schools is very commonly of this type. When military training is taken in its broad sense, it means that kind of training which may not include military drill and yet whose main purpose is to give the youth such an all-round physical, moral, and mental development as to make him capable of rendering service to his country, either as a private citizen, or, after a short period of intensive drill in the training camp, as an efficient soldier. It is upon this distinction that the discussion in this chapter will be based.

1. Laws providing military training in the public schools: With only one exception the laws of the different states concerning military training are based on the narrow meaning of the term.

Arizona-A law providing for the organization, control and equipment of the state normal and high school cadet companies was enacted last year. The law provides:

a. The male students of any state normal or high school having thirty or more such students, fourteen years of age or over, shall be organized into a cadet company or companies.

b. The cadets shall be drilled in accordance with the drill regulations prescribed by the United States army. 
c. Target practice shall constitute a part of the instruction to be given.

d. The training shall not exceed one-half hour each day.

e. For the organization and supervision of this work a Normal School and High School Cadet Commission shall be created.

Indiana-In March, 1917, the State Legislature passed a law regulating the system of military training but making no specification of the kind of training to be given. The two main points of the law are as follows:

a. Whenever a high school in the state institutes a system of military instruction, it shall be authorized to receive arms, ammunition and equipment from the United States government and pay out of the special school fund all the necessary expenses.

b. No system of military training or education shall be instituted or carried on in any school, unless the same be under the supervision of an instructor detailed for that purpose by the federal government, or a competent person certified by the state board of education.

Louisiana-An act requiring the teaching of military science and tactics in all the high schools was passed by the state assembly in July, 1916. The law reads :

"Section 1. Be it enacted by the General Assembly of the State of Louisiana, That, in addition to the branches in which instruction is now given in the public schools of the State of Louisiana, instruction shall also be given to the male pupils thereof whenever practicable in all grades higher than the eighth grade in the principles and practices of military science and tactics, especially with reference to the duties of the soldier and object of general military interest.

"Section 2. Be it further enacted, etc., That in all grades of the public schools of the state higher than the eighth, at least one hour a week shall be devoted to instruction, study and practice of military science and tactics."

Michigan-The Act requiring the establishment of an optional course of military training in all high schools in the state reads as follows:

"Section 1. Hereafter it shall be the duty of all boards of education or boards of trustees of school districts maintaining one or more high schools within their respective districts to establish a course of military training for such high school or high schools, such course to be optional with the students of such high schools: Provided, That nothing herein 
contained shall apply to cities or villages having less than five thousand population.

"Section 2. Failure or neglect upon the part of any board of education or board of trustees of any school district to maintain a course of military training, as provided in this act, shall subject said board to removal from office, after a hearing with proper notice, by the State Superintendent of Public Instruction."

New Hampshire-A law was passed last year which authorizes the public schools to include military drill and physical exercises in the courses of instruction. But what kind of instruction and how much time should be given were entirely left to the discretion of the local school boards.

Oklahoma-The state law authorizes the local school boards to provide for military training, athletic contests between schools, and physical examination of pupils. The boards are also authorized to accept assistance from the war department of the United States and the National Guard of the state for the purpose of military drill and training. The law further provides that a Board of Control, consisting of five members, shall be created for the carrying out of these provisions.

Oregon-The state law only recognizes the military training in the public schools as lawful, but makes no further provision.

In those states where no laws have been enacted on this subject, many cities have taken special action for its introduction. The following resolution adopted by the school board of Pueblo City (District No. 20), Colorado, may be considered as typical.

"Resolved that Central High School maintain a prescribed course of military training extending through two years of the high school course. Such training to be open to all boys as a voluntary and elective study, provided that when elected, the study shall be continued for at least one year and shall not be dropped within that time except by permission of the school management for adequate reasons.

"The high school will give credit for military training to the extent of one unit of the total requirements for graduation, one half unit per year, provided further, that such credit shall be given on condition that the course in military training consist of not fewer than two hours a week for not fewer than thirty weeks of a school year and the conduct of a camp for not less than two weeks each school year.

"The actual teaching of the military training shall be done by a regular teacher in the school. When possible, the teacher 
shall be the teacher of physical education. This work shall be done, when such arrangements are feasible, under the direction and supervision of an officer of the regular army detailed for that purpose. The teacher shall make such preparation for this work as may be directed by the Board of Education."

The first and the only state which has enacted a law on military training in its broad sense is the State of New York. In 1916 the state legislature passed the so-called "WelshSlater" bills, making military and physical training compulsory in the secondary schools of the state for all boys above 16 and under 19 years of age. The essential points of the law are as follows:

The Military Commission-The law requires the establishment of a military commission composed of the Major General commanding the National Guard ex-officio, a member to be appointed by the Board of Regents of the university, and a member to be appointed by the governor. The duty charged to the Commission was that it shall "recommend from time to time to the Board of Regents the establishment in such schools (elementary and secondary), of habits, customs and methods best adapted to develop correct physical posture and bearing, mental and physical alertness, self-control, disciplined initiative, sense of duty and the spirit of co-operation under leadership."

Compulsory Physical Training-The law also requires the instruction in physical training and kindred subjects for all male and female pupils above the age of eight years in all elementary and secondary schools. The kind of physical training shall be determined by the Military Training Commission, and the time spent for it shall be not less than twenty minutes in each school day.

The private schools in the state are equally responsible for the giving of such courses as prescribed by the Commission. If any private school fails to establish and maintain such courses, attendance upon instruction in such school shall not be deemed substantially equivalent to instruction given to children of like ages in the public school or schools of the city or district in which the child resides.

Compulsory Military Training-With regard to military training the law requires that every able-bodied boy between the ages of 16 and 19 must receive military instruction in or outside of the schools. For the boys who are in public or private schools or colleges, the periods of military instruction are to aggregate not more than three hours in each week during the school or college year. For the boys who are outside of the schools, the periods devoted to military training are to aggregate not more than three hours in each week between 
September first of each year and the fifteenth day of June next ensuing. Summer military training camps covering a period of not less than two or more than four weeks are to be established for the training of all the boys under the scope of the law at the expenses of the state. The law further provides that any boy who is lawfully employed in any occupation for a livelihood is exempted from this requirement unless he volunteers.

Critics of the bill advanced arguments against this last provision on the ground that it introduces a miserable class distinction in a public school system, for it associates military affairs with the people of leisure and means and perpetuates the idea that military life is not the business of a wage earner. Acting on the force of such arguments the legislature amended the law in the spring of 1917 in such a way as to include all boys of the said ages to be drafted for the service of the state. The amendment provides that the requirement for technical military training may be met in part, in the discretion of the Military Training Commission, "by such vocational training or vocational experience as will, in the opinion of the Commission, specifically prepare boys of the ages named for service useful to the state, in the maintenance of defense, in the promotion of public safety, in the conservation and development of the state's resources, or in the construction and maintenance of public improvement."

The significant point of this amendment is that it is in accord with the principle on which the national selective draft law is based. It provides for the defensive training of the soldier on the one hand and encourages the vocational training of the boys on the other. For the purpose of investigating and organizing the military equivalent services, a special Bureau of Vocational Training was established. It has been reported that the Commission is doing its best to carry out the provisions of the law both in letter and in spirit.

2. Kinds of military instruction in different school systems: So much for the school laws enacted by the state legislatures or special actions taken by the local school boards, now let us turn our attention to the actual practices of military training which have been in vogue for sometime in some places.

The kind of military training which narrows itself down to a few drills a week with or without arms has been very common wherever such training is given. As an illustration, the training program for the high school cadets of Salt Lake City may be worth noticing.

"Three drills are given per week. The drills are fifty minutes long, from $2: 40$ to $3: 30$ P. M. 
"The school year, October first to May thirtieth, is divided into three periods.

"First Period, October first to November thirtieth.

"First year boys-School of the soldier, school of the squad; manual of arms, port and right shoulder, only.

"Ten minutes of each drill period is devoted to double timing and calisthenics with or without arms.

"Second year boys-School of the soldier, school of the squad, school of the company; manual of arms; competition in manual; some extended order.

"Second Period-December first to February twenty-eighth.

"First year boys-Manual of arms; school of the squad and company; care of and cleaning rifle; calisthenics with and without arms.

"Second year boys-Review of first period; pointing and aiming drills; extended order.

"During this period lectures are delivered to all organizations on the following subjects: First aid; outline of an army; military preparedness in the United States.

"Third Period-March first to May thirtieth.

" First month-Target practice; school of the company and battalion, close order; school of the company; extended order; compulsory combat exercises.

"Second and third months-Battalion parade and review; combat exercises, battalion; target practices; Governor's review."

Among the many schemes of providing a system of broad military training for the school youths the so-called "Wyoming Plan" has been widely heralded by newspapers and highly recommended by educators and military experts for its adoption elsewhere. The plan was originated in 1911 under the direction of Lieutenant E. Z. Steever at Cheyenne. The main feature of the plan is that it offers military training in the form of games. It takes the old lockstep, routine work out of military instruction and introduces into it the principle of competition, co-operation and play based on the natural tastes and instincts of adolescent youth. It utilizes competitive instinct without narrowing competition to the success or failure of any single individual. It develops the spirit of co-operation with ample opportunities for the development of initiative and individuality. It emphasizes the elements of play, yet the serious side of the training is never lost sight of. The whole system is so unique in its nature and so practical in its method that it may not be out of place here to describe some of its essential points in detail.

Training not Compulsory-Military training in Wyoming 
high schools is not compulsory. Indeed, Lieutenant E. $Z$. Steever does not believe that compulsion is necessary, because the fascinating nature of the military games will not fail to secure a large enrollment. The only regulation for this elective course is that, once a boy has selected his course for the year, he must finish it within that period.

There is no other expense for the pupil, except the purchase of a uniform. The State of Wyoming has appropriated a sufficiently large sum to assist the pupils in purchasing the uniforms at almost half of the original price. Upon receiving such state aid, the recipient must sign a certificate agreeing that he will refrain from the use of tobacco in any form.

System of Training-The aim of Wyoming system of military training is not to make soldiers out of the school boys, but to prepare them in such a way as to enable them to become the worthy defenders of the nation when they reach their manhood. For this reason great emphasis has been laid upon physical development and skill in military activities, such as wall-scaling, field firing, etc. ; and the ordinary routine drills have been reduced to the minimum. Beside the regular practice of the different competition units, whose organization I shall describe later, instruction in sanitation, cooking, woodcraft, simple field engineering, scouting, patrolling, etc., is also given.

Organization of Competition Units-According to the Wyoming plan, all cadets are organized into competition units. These are wall-scaling, infantry drill, troop leadership, scholarship, field-firing, and other camp and field activities. In contrast to the common practice of ordinary school foot-ball or baseball teams, of the selected few of the entire student body, the Wyoming plan of organizing these competition units provides an opportunity for the participation of all who elect the course; each unit being made up of an equal number of strong, medium, and weak boys. Take the instance of wall-scaling. The last two men over the wall must be the strongest for they have to help the others over and go over themselves unaided. But no unit is composed of cadets who are all of the "Last-man-over" type. Suppose there are ten competition wall-scaling squads in the school, the twenty strongest students are selected from the cadets at large, and only two of them are distributed to each squad. In the same way the next twenty strongest are selected and distributed, and so on down to the twenty of the weakest. When the squad wins, everybody in the squad receives the same kind of reward and shares the glory of victory with equal pride and honor. 
In case of inter-school competition no school is allowed to. group its strongest men in one squad and let this little group to be the heroes of the day. Each school is required to send a list of all its cadets classified according to their ability to the office of the State Superintendent, and the latter assigns the cadets to different squads in accordance with the principle just mentioned. In case several squads are formed in one school, then they can compete among themselves. The winning squad of this intra-school competition will have the honor of representing the school in the big inter-school tournament.

It is quite obvious that the distinctive feature of the plan does not altogether lie in the system of military games, but in the way the games are played. It allows the weak as well as the strong to play the game and they all have an equal chance to win. The whole system of competition does not consist of marching one squad against the other as in ordinary school athletics, but it encourages one squad to excel the other in team work and accomplishment. One cadet's gain is not another's loss; when one unit wins, some other one does not go down in defeat. Yet each game requires all the energy, ability, skill, team-play and dogged determination of all the participants in order to score a victory. It was reported that once a cadet leader of a scholarship unit visited the other members of the unit night after night for the purpose of coaching them, and that finally his unit won the glory of an unqualified success. Such spirit of loyalty to the group, co-operation among one's associates, and indomitable will to excel others in achievement, are an inspiring illustration of the value of such a system.

Another interesting character in the organization of competition units is that the cadet leaders are selected by the vote of the older cadets at the beginning of each year. The leaders are chosen on the basis of ability and genuine leadership rather than on that of popularity. In case of the election of a popular but inefficient leader, the mistake will be effectively punished by the failure of the unit. The trust of real leadership is thus developed coincidentally with the spirit of self-subordination to the will of the group. This kind of civil training is not possible in any other military organization.

The adoption of the Wyoming Plan in other places-The Wyoming Plan of military training has been tried in many other places, but one of the most important experiments was made in Chicago. Shortly after the declaration of war, Captain E. Z. Steever with a corps of four lieutenants and sixteen sergeants of the regular army undertook to inaugurate 
the Wyoming system of military training in the high schools of certain cities within the central department of the army. Ten officers were assigned to the twenty-three high schools in Chicago. Various competition units were organized among the Chicago high school cadets, and the entire organization was ready in its working order at the beginning of this school year. As to the degree of success of such a trial no report is now available. But I have no doubt that such a simple, yet effective, svstem will not fail to win the confidence and support of the different school systems at this hour of national crisis.

\section{Military Drill versus Broad Physical Education of Semi-Military Character}

In the last section I have tried to make the distinction between military drill on the one hand and the broad military training on the other. Now we should like to ask a very fundamental question: Which one of the two possesses a greater value both from military and educational points of view? John Milton has defined "a complete and generous education as that which fits a man to perform justly, skillfully, and magnanimously all the offices, both private and public, of peace and war." What kind of military training will best accomplish this educational aim is the question we must carefully consider.

In answering this fundamental question the writer is prepared to say very definitely that he is opposed to the introduction of military training in the public schools if such training means only a few perfunctory drills a week. This view seems to have also been held by the majority of educators in this country who have made a careful study of the problem. The reasons for this view may be briefly stated as follows:

In the first place, mere military drill does not prepare a youth to become an efficient soldier. Through the ordinary military drill we may teach the boys to wear their uniforms properly, to keep their shoes shined, to march with 30 inch steps and with a rate of 120 steps per minute, to make proper movements when the orders of "Squad Right" and "Squad Left" are given, and to attain a fair degree of proficiency in the manual of arms. But none of these things are the essential part of a soldier's training. They are fragmentary and elementary in nature. They formed the most important part in the historic military drill practice, but have no functional significance in the modern war as now waged on the battlefields of Europe. Take, for example, the training in the manual of arms. How much practical worth has the 
proper execution of the "Right Shoulder Arms" or "Left Shoulder Arms" to a soldier when the battle is on? How much value has the training in the different classes of firing for the defense of a trench system when machine guns, grenades and other horrible weapons of war have to be used to meet the on-rushing foe? Take another instance, the matter of marching. Of what use is the training in the close-order formation when reinforcements have to be brought up to the threatening point through the communication trenches or in the dark? We can, indeed, be sure that all these kinds of training have very little military value in trench warfare, or in open field battle, or in the hand-to-hand struggle. At the beginning of the European War, it was reported that most of the Belgians who answered the call of their country had no military training whatsoever before they were sent to the front. Yet who would say that they have not made the most heroic defense at the most tragic hour?

However, I do not want myself to be misunderstood on this point as saying that the simple military drill is absolutely useless and futile from the standpoint of military efficiency. I do not for a moment deny the necessity of such drill for the preliminary training of a soldier. It gives discipline. It provides the training for mental alertness in responding to the command. It makes system and order possible in a military organization. It is very necessary that the draftees in the military training camps should be given such kind of training in order "to whip them into shape." But from the practical point of view it is the least important and can also be learned very rapidly and readily. The proficiency in the manual of arms and marching movements can be acquired by any person with normal intelligence within a short time. To substantiate my contention I may relate a case of a very recent date. On the last anniversary of the battle of Lexington twenty Chicago high schools were represented by over 3,200 members of their military training classes in a simple military marching competition. Not a single company had drilled more than four periods with their rifles and the maximum time drilled by the oldest company, both with and without arms, was less than twenty hours. Yet it was reported, " Every lithe, young body was erect, every head straight to the front; every rifle carried just so; every foot in step; every boyish heart set on putting over a win for his company and his school." (Maj. E. Z. Steever and Maj. J. L. FrinkThe Cadet Manual, p. xii.) Whatever other value military drill may have, its introduction into the public school curriculum can not be defended on military ground.

In the second place, a few military drills a week do not 
give sufficient discipline so as to instil the habits of obedience in an adolescent youth. Captain L. C. Andrews has stated that the precise movements of the manual of arms and closeorder formation are not for the purpose of learning how to get about on the battlefield-they will hardly be used at allbut they are for the object of training the mind and body of the soldier into habits of precise unhesitating obedience to the will of the leader. The drill-master commands "Right front into line," not because he wants his men in line especially, but for the purpose of exercising them in an exact performance of that particular movement, of habituating them to move exactly as he has ordered them. So the chief object of this simple drill is to make the obedience to command implicit and automatic. When this object is effectively accomplished, the difficulty in controlling the military units even under the stress of battle will be reduced to the minimum. This is a very brilliant explanation of the object of the drill. But military discipline is not and can not be maintained through drills alone. The habit of obedience can be made automatic only after a long process of training. The soldiers in the training camps live under military discipline in every waking hour of the day and seven days a week. Can the public schools exercise such military discipline over all the boys who are under their care? Obviously not. The schools have no control over the boys after the school hours. The most the schools can do is to require military discipline throughout the school day. But such a policy has not been adopted by any public schools in this country, as far as my knowledge goes. I would like to be convinced that the habits of obedience can be inculcated by a few drills per week and by a system of discipline which begins and ends with the drill hour.

Granting that this can be done. But whether or not the habit of obedience formed during drill hours can be transmuted into other fields is still a question open for investigation. Surely enough the boy learns to obey orders during drill hours, if the drill-master is a good disciplinarian. But he learns to obey orders of a specific kind and under a specific circumstance. Psychologists in recent years have generally denied the doctrine of formal discipline and agreed that the transference of training in one subject to the learning of another is very slight. How much can the specific habits of obedience to military commands be transferred into general obedience to law and authority is a question which can not be answered offhand. The New Jersey Commission on Military Training in High Schools has in its report made a very definite statement on this point. Thus it says: "The discipline of the schools aims, not at isolated acts of obedience 
under special circumstances, but at the habit of obedience to elders and persons in authority. It is a psychological fallacy to suppose that obedience to military authority, obedience exacted under any peculiar circumstances, may automatically be translated into the general habit of obedience." Even though such a statement does not represent the whole truth, it certainly gives us some food for thought.

Furthermore, military drill as conducted in some public schools has failed to maintain strict military discipline even during drill hours. There are many reasons for this, but the chief reason is the incompetency of the military instructor. Superior knowledge is one of the essential qualities of real leadership; and so of the drill-master. He must know his business, if he wants to command the confidence and respect of his men. He himself must know every movement and its proper execution of the drill before he can give the orders correctly and exact unhesitating obedience to them. This is too simple a truth to need any proof or illustration. But let us ask: How many schools are fortunate enough to secure competent men to conduct the military drill? With few exceptions city schools having military training have placed the responsibility of such instruction in the hands of the physical directors. Very few of these directors have proved themselves equal to the new task. They themselves never had the proper military training. They themselves even do not know exactly how the movements they order are to be executed. How can we expect them to be good disciplinarians? One can not fool the adolescent boys. Once they find out that the instructor does not possess "the stuff in him," discipline is hopeless. General Baden-Powell has once said: "Unless you have specially good instructors, amateur military discipline is apt to spoil the boy for standing the real thing when he goes into the service." Shall we "drill the schoolboy and spoil the soldier?"

In the third place, mere military drill does not develop a boy in physical prowess, alertness and endurance. Practically all experts on physical training have come out very strongly against military drill as a means of physical development. Abundant testimonies on this point can be cited, but I shall quote a few of the statements made by those whose opinions based on practical experiences and pedagogical insight should merit our special consideration.

Dr. Ehler, of the University of Wisconsin, says :

"Military drill is an enthusiasm-killing, contempt-developing treadmill. Preparedness involves, primarily and fundamentally, the possession of vitality, endurance, integrity of struc- 
ture, and function of every organ, alertness, bodily skill, selfcontrol, hardihood, courage ; in other words, the fullest development of the physical, mental, and emotional powers, the result of real physical education. Let us not confound drill with training, nor substitute military drill for physical education."

Dr. D. A. Sargent, of Harvard University is strongly opposed to military training and states his opposition clearly and forcibly in the following words:

"Our principal objection to military drill as a physical exercise is that it does not to any extent meet the physiological demands of the body. In other words, it is not of sufficient interest as a means of physical development to arouse any moral earnestness and enthusiasm on the part of the boys. The exercise of the manual is not performed with sufficient force and rapidity to insure the energetic contraction of the mutscles employed. It is essentially a one-sided exercise, bringing into excessive action the elevators of the right scapula, the deltoid, biceps, flexors of the forearm, wrist, and fingers of the right side; while the other muscles, excepting the legs on parade days, do not get sufficient employment to keep in good condition. It does not increase the respiration and quicken the circulation to a sufficient extent to secure the constitutional benefits that should accrue from exercise.

"During the drill the clothing is buttoned close around the chest and natural respiration is hindered. The muscles are not alternately contracted and relaxed but are tetanized, or kept in a state of prolonged tension. This, as we have seen, not only impairs the tone of the muscles used, but also puts an additional strain upon the brain and nervous system at the time when both should be as much relieved as possible. Finally, the mere exercise of the manual of arms does not give sufficient breadth and scope of movement to secure the co-operation of the muscles, and as a training for the central nerve system it is of little or no value.

"In reference to the gracefulness that is thought to characterize the movements of cadets, we can only say it is not the outcome of drilling and marching. The soldier is trained to square corners, straight platoons, and angular movements; curves and embellishments are not encouraged in speech or in action. If you would account for the graceful poise of our national cadets, you should visit West Point in summer and see them from one to two hours a day in charge of the dancing master."

For those who think that the course of military drill has not been fairly represented by the experts of physical education, the opinion of Captain H. J. Koehler, instructor of 
physical training, West Point Military Academy, is specially noteworthy. Thus he says:

"The use of the musket as a means of physical development for any one, be he man or boy, is more than worthless. It is, in my opinion, positively injurious. I deny absolutely that military drill contains one worthy feature which can not be duplicated in every well-regulated gymnasium in the country to-day. A thorough physical training develops all the necessary soldierly qualities to the greatest degrees and it does it without injury. If we have athletes, we shall never be without soldiers."

Experiments have made in a public school of London, England, for the purpose of determining the relative value of physical education and military drill, and the results are decidedly in favor of the former. Thus Dr. W. E. Darby, of London, says:

"It (physical training) should not be military, and for the following among other reasons: Because as a method of physical training military drill is both inadequate and injurious. Experiments, which were conducted in a public school. with a view to ascertain the relative value of gymnastics and of mere drill, showed that the average results yielded by the former were more than three times as great as those yielded by drill alone. Relatively, therefore, this method of physical culture is inferior. . . ."

Not only has military drill been condemned as a means of physical training, but it has also been shown as being actually harmful in its effect on boys who are too young to handle the real weapons and undergo the rigors of adequate instruction. Sir William Ailkin, professor of pathology in the army medical school of England has once said:

"Boys given military training at 18 makes soldiers who are less robust and efficient than men with whom this training was deferred a few years, remaining in civil life until after their bones, heart, lungs, liver, etc., were more matured ard developed. Recruits at 18 show physical immaturity which results only too frequently in their ending in the hospital or being discharged as invalids. Recruits of 18 require two years' special training."

Finally, military drill in the public schools has been defended as a means of teaching patriotism. Now does it or does it not? To my mind, true patriotism can only follow the intelligent appreciation of the national and community life and of one's duty to the welfare of the group. To think that the simple military drill will cultivate in a boy a virile spirit, an ability and willingness. to endure hardships, and a keener sense of duty to serve the community, the state, and the nation 
is nothing short of a great pedagogical illusion. The love of the country and the esprit de corps can never be aroused by having imitation military drills with broomsticks for the rife.e. and school basements or small gymnasium floors for the trill grounds. If military training has any contribution towards the development of one's sense of responsibility, duty, and selfsacrifice, it must be real, it must be broad in scope and practical in nature. The technical drill which is the smallest and the least valuable part of soldier's preparation can never accomplish the object.

In the above few pages I have endeavored to show that military drill alone has no great value both from the military and educational points of view. It can not be the means of character building and physical development. What we need to-day is not the "Shoulder arms" and "Forward march" sort of drill in the public schools, but a broad program of physical education of semi-military character for all the youths of the land, so as to develop in them the physical qualities of health, vigor and endurance, the mental qualities of acumen, control and alertness, and the moral qualities of courage, cooperation and self-sacrifice, in the widest and best sense. All these qualities are at the foundation of good citizenship as well is of practical soldiery. Schools can not and stould not be expected to perform the task of training soldiers in the strict military sense. But schools can and should train the youths in a broad and general way so as to make them physically, morally and mentally fit for fighting the battles of the nation when their service is needed. This task can be accomplished far more effectively by a well-devised system of vigorous physical training under discipline than by military drill.

Before we discuss the content of such broad program of physical education in the light of its practical value as a soldier's preparation and of its adaptability as a part of the public school curriculum, we may first direct our attention to the means and methods by which the European nations have been training their school youths under military age.

"Military instruction, of the exact nature and to the same extent as that given to soldiers, is not found in the schools of any country of Europe except the special military schools." In those countries where the system of universal military service exists the public schools often include military gymnastics in the course of physical education. But in no case have they ever attempted to substitute military drill for the 
well-established systems of physical training. We may take Germany, France, and Switzerland for our illustration. ${ }^{1}$

Germany-In Germany military drill was introduced into the city schools of Prussia as early as the beginning of the nineteenth century. But shortly after the Napoleonic wars, a thorough system of military preparedness for all males was adopted, and the matter of military training in schools was made no longer necessary. It was not until the outbreak of the European war that an emergency measure was undertaken by the schools to prepare the youths approaching the military age for their early service in the army. In 1914 a joint decree was issued by the Prussian ministries of war, ecclesiastical and educational affairs, and the interior, requiring that all boys over 16 years of age, not yet in active service, should receive preparatory military training for the duration of the war. In response to this decree many schools have introduced military instruction in connection with gymnastics as a part of the prescribed program. The time allotted to this work averages two hours a week.

Before the war, the German school youths could obtain military instruction only from voluntary organizations which have been in existence outside of the school. Among these organizations the federation of Jugendwehren (juvenile military organizations) is the best known. The chief purpose of this organization is to train the boys in long marches, field exercises, and maneuvers, as well as exercises in the activities of auxiliary corps of the army. It does not limit its membership to the school boys, but the great majority of its members are the pupils of various schools.

Next to Jugendwehren the organization of Pfadfinder (pathfinder) has had a very rapid growth in Germany. In 1912 the federation of pathfinders had a membership of 24,000 , with 600 field masters. The training program of this organization is essentially the same as that of the Boy Scout.

Jungdeutschland (Young Germany) is another organization which tends to prepare boys of school age for military duty by means of exercises of a direct military character. It was organized by General Field Marshal von der Goltz in 1911, and its activities comprise drills, gymnastics, bicycling, marching, field exercises, patrolling, small feats of military engineering, etc.

France-Since the disastrous defeat of 1870 France has paid special attention to the preparation of her youth for

1 For detailed information, see Military Training of Youths of School Age in Foreign Countries. U. S. Bureau of Education, Bulletin No. 25, 1917. 
military service. As early as 1880 physical training including military drill was made obligatory in all public schools.

In the primary schools, the prescribed programs of military instruction are as follows:

"Middle division.-Exercises in marching, alignments, formation of squads, etc. Preparation for military service.

"Higher division.-School of the soldier without arms. Principles of the several steps. Alignments, marches, countermarches, and halts. Changing the direction."

In higher elementary schools, the "preparatory military exercises" consisting of advanced drills and maneuvers are added to regular gymnastics.

However, this system of military training as a component part of the prescribed course of physical education has not been approved by the leading educators in France, although it has been recognized as preparatory training for military service. Thus one authority says: "Military training involves serious inconveniences with regard to hygiene. It implies rigid discipline, which is condemned by true pedagogy. Outside of that it produces results that are only partial, limited and special."

Szitzerland-Among all the systems of universal military service the so-called "Swiss System" has been highly recommended for its adoption in this country. The essential feature of the system is the provision of a short period of actual military training and the requirement of all public schools to give "Preparatory Gymnastics." In an Act for the military organization of the Swiss Republic, it was required that the cantons should provide for a course in calisthenics for young men during their attendance in the public schools, and this calisthenic exercise should be administered by instructors trained for the work either in the normal schools or in the schools for physical training. The law also provides that the Confederation would encourage all associations and all efforts toward the bodily development of its young men from the time of their leaving school until incorporated in the army.

In accordance with the provision of this Act, the preliminary military training is conducted in two forms: (1) compulsory preparatory gymnastics for all the boys during the entire legal school age; and (2) voluntary cadet corps; such corps for drill with arms, corps for drill without arms, and corps for target practices, are greatly encouraged by the government in various ways. Military training as we find in some school systems in this country does not exist in the public schools of the Swiss Republic.

Enough examples have been cited from European countries. 
We may now take a few examples from some of the progressive states in this country in this connection.

New Jersey-Acting on the recommendation of the Commission on Military Training in High Schools the State Legislature passed a very comprehensive law in March, 1917, for the establishment of a state system of physical education in all the public schools. The general provisions of the law are :

1. A course in physical training shall be established and made a part of the courses of instruction in the public schools. No pupil can be excused from taking such training except those in the Kindergarten.

2. The time devoted to such training shall aggregate at least two and one-half hours in each school week.

3. Such course shall be adopted to the ages and capabilities of the pupils in the several grades and departments and shall include the following points:

a. Exercises, calisthenics, formation drills, instruction in personal and community health and safety and in correcting and preventing bodily deficiency.

b. Instruction in the privileges and responsibilities of citizenship, as they relate to community and national welfare, with special reference to developing bodily strength and vigor, and producing the highest type of patriotic citizenship.

c. For female pupils, instruction in domestic hygiene, first aid and nursing shall be added.

4. At the discretion of the state board of education, military training may also be included in such course.- In case the said board decides not to include it, any local school board may submit the whole question to referendum vote.

California-The state legislature enacted a law concerning the organization and supervision of courses in physical education in the elementary, secondary and normal schools of the state in May, 1917. The law includes:

1. The board of education of each county, and city shall prescribe suitable courses of physical education for all pupils in the day elementary school and the board of high school district for all those in the high school.

2. The aims and purposes of such courses are: (a) "to develop organic vigor, provide neuro-muscular training, promote bodily and mental poise, correct postural defects, secure the more advanced forms of co-ordination, strength and endurance, and to promote such desirable moral and social qualities as appreciation of the value of co-operation, self-subordination 
and obedience to authority, and higher ideals, courage and wholesome interest in truly recreational activities; (b) to promote a hygienic school and home life, secure scientific supervision of the sanitation of school buildings, playgrounds and athletic fields, and the equipment thereof."

3. A State Supervisor of Physical Education shall be appointed by the State Board of Education. He shall exercise general supervision over the courses of physical education and all the athletic activities in the public schools of the state.

Maryland-A law enacted very recently requires that all public schools must establish and maintain a course of physical education and training for pupils of both sexes during the following minimum periods: (a) in the elementary schools at least fifteen minutes in each school day and also at least one hour of directed play outside of regular classroom work in each school week; and (b) in public high schools at least two hours of directed play or athletics for all pupils outside of class work in addition to the one hour gymnastic exercises in each school week. For the purpose of carrying out this provision a State Supervisor was also provided.

Beside these three states, the General Assemblies of Rhode Island and Delaware have also enacted laws with regard to this important problem. But they are much less comprehensive and specific than those just mentioned.

In addition to these state legislations, a movement is now on foot to secure federal legislation for the establishment of a universal system of physical education throughout the country. In the Conference on Physical Education called by Commissioner Claxton at Atlantic City in February, 1918, the following resolutions were adopted.

" 1 . That a comprehensive, thoroughgoing program of health education and physical education is absolutely needed for all boys and girls of elementary and secondary school age, both rural and urban, in every state in the Union.

" 2 . That legislation, similar in purpose and scope to the provisions and requirements in the laws recently enacted in California, New York State, and New Jersey, is desirable in every state, to provide authorization and support for state wide programs in the health and physical education field.

"3. That the United States Bureau of Education should be empowered by law, and provided with sufficient appropriations, to exert adequate influence and supervision in relation to a nation-wide program of instruction in health and physical education.

" 4. That it seems most desirable that Congress should give 
recognition to this vital and neglected phase of education, with a bill and appropriation similar in purpose and scope to the Smith-Hughes law, to give sanction, leadership and support to a national program of health and physical education; and to encourage, standardize and, in part, finance the practical program of constructive work that should be undertaken in every state.

" 5. That federal recognition, supervision and support are urgently needed, as the effective means, under the Constitution, to secure that universal training of boys and girls in health and physical fitness which are equally essential to efficiency of all citizens both in peace and in war."

From all the evidence at hand we may safely say that the general tendency in this country is towards the introduction of a broad system of physical education into the prescribed school curriculum instead of military training in its narrow sense. This is the only sensible thing for the schools to do, because they lack the time, the means and the professional ability to provide a genuine and real system of military training comparable to that given to the soldiers. Now we may ask: What kind of physical education should we adopt in order to achieve the purpose of preparedness?

Copious literature has been written on this problem in the past two or three years, and many valuable suggestions have been made. In some places the measures of health examination, provision of healthful environment in home and school, and instruction in health problems have been included in the program of physical education. Broad as this conception of physical education is, I wish to suggest the incorporation of the program and methods of the Boy Scout in any scheme of physical training which may find its place in any school system. This is not the place to discuss the Boy Scout program. But from the military and educational points of view, we may see what contributions scouting education does have to offer.

In the first place, scouting offers the. very best training in the military sense to the adolescent youths. Experience teaches us that modern military training is an exceedingly complex affair. A good soldier must have not only strong physique, great endurance, and knowledge of military tactics, but also practical ability in doing many things upon which the efficiency and success of an army depends. He must know how to build roads, put up his tent, and take care of various kinds of motor machines. He must know the principles of personal hygiene, first aid, and camp sanitation. He must know how to take care of himself, such as what to do about 
a blister and how to cook a simple meal. All these and many other things are the fundamentals of a soldier's training; and these are the very things which the scout program includes. As an illustration of this point, the introductory statement in the Boy Scouts' Handbook (1917) is very noteworthy.

"A Scout! He enjoys a hike through the woods more than he does a walk over the city's streets. He can tell North or South from the moss that grows on trees and East from West by the shadows that trunks and branches cast. When matches are forgotten he laughs and proceeds to kindle a fire by rubbing two sticks together or by striking steel on flint. The fire once started, what a breakfast, dinner, or supper he can prepare out there in the open! Does he enjoy the meal? Just watch him and compare his appetite with . that of a boy who lounges at a lunch counter in a crowded city.

"A Scout does not run away or call for help when an accident occurs. He devotes all his strength and energy to assisting those who are in need. If a person has been cut he uses his first aid knowledge in stopping the flow of blood, gently and carefully binds up the wound, then, if necessary, he seeks other assistance. If a person has been burned his knowledge tells him how to alleviate the suffering. If any one should be dragged from the water unconscious, a Scout at once sets to work to restore respiration and circulation. He knows that not a minute can be lost.

"A Scout can talk to a brother Scout without making a sound by signaling with flags; or by tapping on a log he can imitate the click of a telegraph key, and in either manner he can spell out words and sentences.

"A Scout can tie a knot that will hold, he can climb a tree, the ascent of which seems impossible to others, he can swim a river, he can patch a tent, he can mend a tear in his trousers, he can tell you what weeds are poisonous and what are not, he can sight nut-bearing trees from a distance; if living near ocean or lake he can reef a sail and take his trick at the wheel, and if near any body of water at all he can pull an oar or use paddles and sculls; in the woods he knows the names of birds and animals; in the water he tells you the different varieties of fish."

In the second place, scouting education offers the very best means of character building. Dr. James E. Russell, in commenting on scouting education, once said: "As a teacher, I take my hat off to Sir Robert Baden-Powell, the genius who in a decade has done more to vitalize the methods of character training than all the schoolmen in this country have done since the Pilgrims landed on the New England coast." In the public schools we teach the precepts and neglect the 
practice. We preach the virtues but lay no emphasis upon participation. We know full well that mere instruction is ineffective in character building, yet our indolence has always made us follow the line of least resistance. But scouting education just reverses our common practice. It teaches the boy to translate the Golden Rule into concrete deeds and thus enables him to incorporate it into the fabric of his moral life. On becoming a tenderfoot every boy must take the scout oath: "On my honor, I will do my best (1) to do my duty to God and my country and to obey the scout law; (2) to help other people at all times; (3) to keep myself physically strong, mentally awake, and morally straight." This simple oath has a very significant meaning to the boy. It means the solemnity of the occasion on becoming a scout. It means that he must do something to fulfill his duty. This oath is further reinforced by the twelve commandments stated in positive terms. The scout is trustworthy, loyal, helpful, friendly, courteous, kind, obedient, cheerful, thrifty, brave, clean and reverent. Each one of these laws sounds a bit grandiloquent, but it is illustrated by the simplest and most concrete duties of a boy's life. The scout's duty is to do a good turn daily, but he does it on his own initiative and out of his own free will. In contrast to the military discipline, which is always mechanical and autocratic, the scouting program seems to be so nicely adjusted and so evenly balanced as to inculcate the spirit of self-subordination and the habits of obedience on the one hand and to provide ample opportunities for the development of originality and leadership on the other.

In the third place, the means and methods of scouting education appeal to the boy's interest and are adapted to the boy's nature. The boy in his early teens is essentially a savage. He has an abundance of energy and a great variety of interest. $\mathrm{He}$ is a great explorer. He loves adventure. He seeks opportunities to give expressions to his inner cravings and instinctive desires. School is exceedingly irksome to him, because pedagogues are often short-sighted and pinheaded and do not know how to supply his psychic needs. From this psychological point of view we find the secret of success of the Boy Scout movement. It gives the boy a chance to make use of all his powers, physical, mental, and moral. It directs his interests to the right channel and at the right ends. It makes him self-reliant yet obedient, courageous yet restrained, virile yet courteous, aggressive yet always respectful for the right of others.

Most of the scouting activities are in a form of play, and most of the play is to be had out of doors. There the scout may play the part of an Indian, or a frontiersman, or a 
cowboy, to work off his wild spirit in the most wholesome manner. There he learns about the stars, the moon, and the sun, about the frost, snow, rain, clouds and winds, about the trees, flowers, birds, and insects. There he explores the country and finds out every path and by-path. There he learns to use properly his eyes, ears, nose, and senses of taste and touch. There he is taught to deal with various accidents -ice-breaking, electric shocks, drowning, run-away carriages, and so on. There he must prove that he can make a fire with or without matches, cook a hunter's stew, skin and cook a rabbit, or pluck and cook a bird. There he acquires the knowledge of scores of other activities which are susceptible of direct and immediate application to everyday life. The best thing about this whole scheme of training is that "every task in scouting is a man's job cut down to a boy's size." It appeals to the boy's interest because he wants to "behave like a kid, but be treated like a man." If the interest of the children should be the first consideration of modern education, the means and methods of scouting seem to be well-nigh pedagogically perfect in every respect.

From the standpoint of preliminary military training and sound pedagogy I have praised the scouting program and method and urged the incorporation of scouting activities into the school curriculum. But with regard to the entire system of broad physical training the following general outline may be offered.

1. The school day must be greatly lengthened. Seven or eight hours a day and six days a week should be a possibility.

2. For the children between 6 and 12 years of age, at least half of the school day should be given to physical exercise and organized play.

3. For the children between 12 and 16 years of age the program and method of the Boy Scout should be adopted. The physical director should be the scout master, and every boy should be made a "good scout." At least from 15 to 18 hours a week should be given to the activities of scoutcraft. Two whole afternoons a week (perhaps to include evenings too), say Wednesdays and Saturdays, should be made available for long hikes, trips to swimming places, etc. Week-end camping may also be possible.

4. For the boys between 16 and 18 years of age, the Wyoming system of military training may also be included in the program in addition to those activities just mentioned. Summer camps covering a period from four to six weeks should be established at the expense of the State, and their attendance should be made obligatory to all boys. In these 
camps intensive military training should be given and strict military discipline should be maintained. In this connection the program carried out by the Military Training Commission of New York State last summer should be worthy of adoption.

In conclusion, I may say that (a) the kind of military drill which we find in some school systems in this country has no place in the public school curriculum. It is a sheer waste of time, and has no value, either military or educational. (b) A genuine system of military instruction, of the exact nature and to the same extent as that given to the soldiers, can not be provided by the school for lack of time, means, and professional ability. It has not been found in the public schools of any country in Europe. (c) A broad program of physical education of semi-military character should be adopted by all the schools in the country. It may necessitate the reorganization of the systems of school administration and school instruction to some extent. But we should spare no effort in putting it into practice, if it is workable. "Better citizenship" is the educational slogan of to-day; and a good citizen can never fail to be a good soldier. 